\title{
Achieving the Objectives of Arts and Cultural Education in Slovenian Pre-Service Teacher Training
}

\author{
Olga Denac ${ }^{1}$, Branka Čagran ${ }^{2}$ \\ ${ }^{1}$ Department of Pre-School Education, University of Maribor, Maribor, Slovenia \\ ${ }^{2}$ Department of Primary Education, University of Maribor, Maribor, Slovenia \\ Email: olga.denac@uni-mb.si
}

Received October $1^{\text {st }}, 2012$; revised November $5^{\text {th }}, 2012$; accepted November $16^{\text {th }}, 2012$

\begin{abstract}
The paper presents the results of research involving students from across Slovenia, exploring opinions on whether the objectives of arts and cultural education in their higher education have been met so far and their attitude towards education and the arts. The results of the research show that the general aims of arts and cultural education were more frequently incorporated in the study process than the aims relating to developing an attitude towards cultural heritage. Students from various study programs agree in particular on the need for team planning of the learning process, and on the importance of art education in the development of the individual's creative potential. However, they agree less on measures aimed at improving the quality of art education and viewpoints relating to the content of future preschool and school teacher higher education. The results relating to the research aims also display statistically significant differences between study programs. Arts and cultural education in the education system was given higher importance by students of social sciences, preschool education and class teaching than by students of natural sciences.
\end{abstract}

Keywords: Education; Arts; Culture Educations; Objectives of Arts; Cultural Education

\section{Introduction}

In accordance with lifelong learning competences, in particular the competence relating to cultural awareness and expression, which includes extending personal growth, constructive control of emotion, identity, innovation and creativity, critical thinking and intercultural communication, arts and cultural education serves as a starting point in the co-creation of culturally conscious and aesthetically sensitive individuals (young people). Because of the coexistence in the common European region, we should also reconsider the role and the importance of arts in education. "The changing society shows a need to develop responsibility towards preserving and passing the cultural capital from generation to generation" (Borota, 2008: p. 3).

As a result, arts and cultural education in the 21 st century is becoming one of the more important topics within education and culture (PožarMatjašič \& Bucik, 2008), which is corroborated by a number of documents, such as The Arts and Education (2004), Road Map for Arts Education (2006), or Reinvesting in Arts Education (2011). In Slovenia, these correspond with the National Guidelines for Arts and Cultural Education (2009), the Proposal of Arts and Cultural Education (2009) and the National Cultural Programme 2008-2011. Moreover, The European Commission has underlined the importance of creativity and innovation and the role of culture and creativity with the report Communication on a European Agenda for Culture in a Globalizing World (2007), the Work Plan for Culture 2008-2010 (2008) and by declaring 2008 the European Year of Multicultural Dialogue and 2009 the European Year of Creativity and Innovation. Let us mention only some of the key recommendations in these documents: arts education should be obligatory at all levels of education; arts classes should be taught with the help of the latest information-communication technologies; classes should be made more appealing by including meetings with artists and visits to cultural institutions.

Taggart et al. (2004) point out that the majority of European countries have arts education aims defined in their curricula, while a comparative study by the Eurydice network (2009) offers an insight into the planning and implementation of arts education across curricula in 30 European countries.

It positions art in the curricula in the following two ways: as an integrated single unit consisting of various arts subjects (art) or as a series of individual arts subjects (fine arts, musical classes, dance classes, drama, etc.) For this reason, countries vary in the level of detail they use to define the aims and results of arts education; however, the most common general aims in the majority of European curricula are: developing creativity, developing arts knowledge and abilities, knowing and understanding; developing critical evaluation and aesthetic judgment; understanding cultural diversity and the importance of cultural heritage and developing skills in personal expression. Besides these learning aims, it is necessary to mention the general learning aims in the curricula that can be linked to arts and culture, such as the encouragement of cross-curricular integration between the arts and other subjects.

The analysis of Slovene higher education training programs for preschool and school teachers shows that both the content and objectives of arts and cultural education are adequately represented in the curriculum, although to varying degrees: to a larger extent, naturally, in arts and humanities courses in preschool education and class teacher programs and to a smaller extent in the natural sciences.

As arts and cultural education allows for numerous connections within a range of subjects, a didactic approach involving cross-subject integration can serve as a starting point for the 
implementation of arts and cultural education aims within the learning process. By including arts education aims, content and methods of work in other subject areas, we develop an attitude towards art (Schirrmacher, 2002; Thompson, 2006). Experience shows that cross-subject integration allows pupils to develop interest and motivation for learning and to deepen their understanding and use of knowledge. Besides this, they achieve higher grades, develop better interpersonal relationships and motivation for learning, and demonstrate self-confidence, mutual cooperation and understanding; they are also able to better recall and understand the learning materials and can transfer the acquired knowledge and abilities between different subject areas (Bevc, 2005). Although cross-subject integration in Slovenia is still to be fully accepted professionally, research suggests that it is already often present in teaching.

It is increasingly obvious that state institutions and publications offer theoretical perspectives on the importance and role of arts and cultural education, which are taken into account by curriculum designers, but little guidance on concrete didactic approaches. This raises the question of the extent to which the teachers (class teachers, subject teachers of arts subjects, subject teachers of other subjects, such as, for example, history, mathematics..., teachers in higher education) can implement the aims of arts and cultural education in the present and future school curriculum.

Teachers who teach arts subjects play a key role in developing pupils' creative abilities (Zbainos \& Anastasopoulou, 2012). However, a study on the impact of culture on creativity (KEA European Affairs, 2009), singled out teacher training as one of the main areas that has to be improved in order to establish a creative learning environment in schools, underlining why it matters who teaches arts subjects and how well these teachers are trained.

The quality of arts education is influenced by cooperation between subject teachers, class teachers and recognized artists (forms of partnership: visits to museums, galleries, musical and theatre performances, visits by artists to schools, etc.), while successful cooperation is based on mutual knowledge and understanding of given aims and mutual respect for competences on both sides.

Another aspect of this issue that many authors have highlighted is the problem of ensuring good-quality teaching in the field of arts and cultural education (Sharp \& Le Métais, 2000; Taggart et al., 2004; Bamford, 2006), and in the past, not enough attention was paid to studies that monitored how well the arts were taught. Since the effective planning and implementation of the educational process involving arts disciplines depends mainly on the teacher, it was our objective in this extensive empirical research project on culture and art in the Slovene educational sphere to analyse the opinion of students, i.e., future preschool and school teachers, on arts and cultural education.

\section{Aims of the Empirical Research}

The research aims to establish:

- the opinion of students on achieving the objectives of arts and cultural education in their former higher education; and

- the attitude of students towards education and the arts.

Concerning our stated primary goals, we wish to verify the existence of differences in regard to study program (preschool education, class teaching, natural sciences, social sciences) and in terms of the students' attitude, examine in particular the role played by study interests.

\section{Methodology}

\section{Research Sample}

The survey involved third-year full-time students from all three Slovenian universities (University of Maribor, University of Ljubljana and University of Primorska). Among the students who fully completed the questionnaire $(\mathrm{n}=552)$ were students of preschool education $(\mathrm{n}=128)$, class teaching $(\mathrm{n}=189)$, natural sciences $(n=98)$ and social sciences $(n=137)$. The applied sample of students is defined at the level of the application of inference statistics as a simple random sample from a hypothetical population.

\section{Data Collection Procedure}

The data were collected through a questionnaire in January 2012. The questionnaire for students comprised closed-type questions (dichotomous questions, questions with verbal and scaled answers) and a five-point Likert scale of viewpoints. It was created in accordance with the following measurement characteristics:

Validity is based on a rational assessment of the test questionnaire by experts for content- and format-related properties (advisors on arts disciplines from the National Education Institute) and its pre-test use.

Reliability was ensured with detailed instructions, singlemeaning, specific questions and a comparison of the answers to questions with similar content. An empirical test was also carried out to verify the reliability of the Likert scale in measuring attitudes. The calculation of Cronbach's coefficient of reliability alpha $(\alpha=.774)$ confirms the reliability of the scale.

Objectivity relies on the prevailing close-type questions.

\section{Data Processing Procedures}

The data were processed at the descriptive and inferential levels. We used frequency distributions (f, $\mathrm{f} \%$ ), mean of degree of agreement $(\bar{x})$, parametric (analysis of variance) and non-parametric tests $\left(\chi^{2}\right.$-test, Kruskal-Wallis test).

\section{Results and Discussion}

\section{Opinions of Students on Achieving the Objectives of Arts and Cultural Education in Their Former Higher Education}

More than half of the students feel that their higher education up to this point has often included the following objectives of arts and cultural education: developing free and critical thinking $(58.3 \%)$, enhancing imagination $(54.9 \%)$, raising awareness about the natural and cultural environment $(52.0 \%)$ and encouraging cross-subject integration $(50.5 \%)$. On the other hand, they categorised the following factors as seldom occurring: developing aesthetic sensibility (66.7\%), expressing one's own culture $(64.3 \%)$, expressing other nations' cultures $(62.0 \%)$, forming arts and cultural values $(60.7 \%)$, developing an awareness of cultural identity $(60.3 \%)$, getting to know other cultures (59.1\%), developing critical attitudes towards culture and the arts $(57.1 \%)$, understanding cultural diversity (54.5\%), getting to know one's own culture (55.1\%) and connecting the pupil's 
emotional, intellectual, physical and creative abilities (50.9\%).

The students' opinions led to the conclusion that university teachers pursued the general goals of arts and cultural education in their teaching, such as developing free and critical thinking, enhancing imagination, and raising students' awareness of the natural and cultural environment. They were, however, less successful in achieving goals with which we help shape a positive attitude towards cultural values, expressing one's own culture and expressing other nations' cultures and towards aesthetic sensibility, despite the fact that the study programme courses in which most of the questioned students were enrolled offer numerous possibilities for implementing the stated objectives of arts and cultural education.

A statistically significant difference exists in the students' opinions on the frequency of realization of the goals of arts and cultural education during their university studies in relation to their study program:

- The majority of students of preschool education estimate that goals developing aesthetic sensibility $\left(\chi^{2}=72.221, P\right.$ $=.000)$, developing emotional intelligence $\left(\chi^{2}=15.772, P\right.$ $=.015)$, enhancing imagination $\left(\chi^{2}=17.792, P=.007\right)$, developing critical attitudes towards culture and the arts $\left(\chi^{2}=\right.$ $35.427 P=.000)$, forming arts and cultural values $\left(\chi^{2}=\right.$ 29.764, $P=.000)$, raising awareness about the natural and cultural environment $\left(\chi^{2}=26.331, P=.000\right)$, encouraging cross-subject integration $\left(\chi^{2}=24.020, P=.001\right)$, connecting pupil's emotional, intellectual, physical and creative abilities $(50.9 \%)$ (tendency of difference $\chi^{2}=12.415, P$ $=.053$ ), frequently occurred in their higher education,

- The majority of students of social studies estimate that the goals related to getting to know one's own culture $\left(\chi^{2}=\right.$ $37.422, P=.000)$, expressing one's own culture $\left(\chi^{2}=\right.$ 21.620, $P=.001)$, developing an awareness of cultural identity $\left(\chi^{2}=32.996, P=.000\right)$, getting to know other cultures $\left(\chi^{2}=28.451, P=.000\right)$, understanding cultural diversity $\left(\chi^{2}=30.391, P=.000\right)$, expressing other nations' cultures $\left(\chi^{2}=19.922, P=.003\right)$, encouraging tolerance of different cultures $\left(\chi^{2}=27.003, P=.000\right)$, developing free and critical thinking (tendency of difference $\chi^{2}=11.185, P$ $=.083$ ), also frequently occurred in their education.

- The majority of natural science students, however, report that the objectives of arts and cultural education were seldom or hardly ever included in their former higher education.

The results of our research show that university teachers who teach students of preschool education strive to incorporate the general aims of arts and cultural education as much as possible, whilst university teachers in social sciences are largely aware of the importance of the aims relating to the development of a positive attitude toward cultural values, towards expressing one's own culture and expressing other nations' cultures and raising awareness of the students' cultural identity. This can also be attributed to the significantly larger proportion of multicultural content in the social-science study programs. Although this content is also included in the syllabi of Class Teaching and Preschool Education study programmes, the research results indicate that teachers only seldom included them in the learning process. Planning the objectives of arts and cultural education is undoubtedly subject to the chosen study program, to the syllabi and curricula of the subject fields. However, we would expect of the teachers teaching courses in natural sciences to include more goals of arts and cultural education in the learning process.

Numerous studies on the effects of arts-integrated curricula show that "arts integrated teaching has the potential to develop many typically unmeasured facets of student development" (Horowity, 2004 as cited in Russel \& Zembylas, 2007: p. 293) and that the effects of in-and-through-the-arts-learning are difficult to measure. The study "Learning through the Arts" (ibid.) thus revealed that the effects of learning through the arts are not reflected in the learning achievements in mathematics and language. However, it is possible to determine the advantages of an arts curriculum on the level of pupils' motivation and their emotional, physical, cognitive and social development.

If we understand the integration of arts as meaning "connections between two or more of the traditional disciplines or subjects" (Russel \& Zembylas, 2007: p. 289) and also as a "conceptual term to refer to activities that strive to infuse the arts across school disciplines" (ibid.), then we can presuppose achieving the aims of art such as, for example, developing critical thinking, enhancing imagination, care for the natural and cultural environment, creating individual creative potential, etc., in various subject areas (including non-arts). It is important that integration of the arts is not seen simply as a transfer of the aims and content of learning but as "a cultivation of habits of mind" (Bresler, 2006). Such an approach, of course, first and foremost requires professionally qualified teachers, as "teachers feel uncomfortable when asked to teach in an integrated manner, unless they have had opportunities to develop deeper knowledge in the subjects they are trying to integrate" (Russel \& Zembylas, 2007: p. 296).

\section{Students' Attitudes towards Education and the Arts}

Students used a five-level scale (5-I strongly agree, 4-I agree, 3-I neither agree nor disagree, 2-I disagree, 1-I strongly disagree) to express their attitude to four sets of attitude, namely towards:

- the significance of arts education;

- measures for raising the quality of arts and cultural education;

- contents for educating future teachers;

- team planning of educational work.

We analyzed both the individual statements and sets of attitudes as a whole (see Table 1).

The point agreed on to the greatest degree among students from different study programs is the need for the team planning of education, in particular team work of class teachers and collaboration of teachers from various subject fields. They agreed slightly less on confirming the importance of art education. The rankings of types of individual sets of views and individual assertions within them therefore indicate that students attach great importance to the following benefits of arts education: the development of the individual's creative potential; the raising of students' motivation for studying; encouraging the understanding of different social cultures; the development of personal and collective identities; the development of interdisciplinary knowledge, skills and competences. However, they attached less importance to arts education in resolving the problems of modern society. A slightly lower, but similar general average rate of consensus, was observed in the set of assertions relating to the measures for raising the quality of arts and cultural education, 
Table 1.

Statements in individual sets of attitudes arranged according to mean of degree of agreement $(\bar{x})$.

\begin{tabular}{|c|c|c|c|c|c|c|c|}
\hline \multicolumn{2}{|l|}{ Importance of arts education } & \multicolumn{2}{|c|}{$\begin{array}{l}\text { Measures for raising the quality of arts } \\
\text { and cultural education }\end{array}$} & \multicolumn{2}{|l|}{ Content of future teacher training } & \multicolumn{2}{|c|}{ Team planning of education work } \\
\hline Statements & $\bar{x}$ & Statements & $\bar{x}$ & Statements & $\bar{x}$ & Statements & $\bar{x}$ \\
\hline $\begin{array}{l}\text { Arts education allows } \\
\text { individuals to develop their } \\
\text { creative potential }\end{array}$ & $\begin{array}{r}\mathrm{E} \\
4.172 \mathrm{~b} \\
\mathrm{c} \\
\mathrm{g}\end{array}$ & $\begin{array}{l}\text { Encouragement of partnership } \\
\text { between schools, artists and } \\
\text { cultural institutions should be } \\
\text { given more attention }\end{array}$ & 3.882 & $\begin{array}{l}\text { Training at the faculty offers } \\
\text { future teachers good professional } \\
\text { knowledge }\end{array}$ & 13.795 & $\begin{array}{l}\text { Planning the learning process at } \\
5 \text { class level should include } \\
\text { teamwork among class teachers }\end{array}$ & 4.199 \\
\hline $\begin{array}{l}\text { With a well-guided teaching } \\
\text { process, arts education raises the } \\
\text { level of pupils' motivation and } \\
\text { active cooperation }\end{array}$ & $\begin{array}{r}\mathrm{It} \\
4.014 \mathrm{a} \\
\mathrm{ft}\end{array}$ & $\begin{array}{l}\text { It is necessary to provide } \\
\text { t additional professional training } \\
\text { for teachers about arts education }\end{array}$ & 3.857 & $\begin{array}{l}\text { Training at the faculty offers } \\
\text { future teachers good general } \\
\text { knowledge }\end{array}$ & 3.759 & $\begin{array}{l}\text { Planning the learning process at } \\
9 \text { subject level should include } \\
\text { teamwork of teachers from } \\
\text { various subject areas }\end{array}$ & 4.140 \\
\hline $\begin{array}{l}\text { Arts education encourages } \\
\text { understanding between different } \\
\text { societies and cultures }\end{array}$ & $\begin{array}{r}\mathrm{A} \\
3.915 \mathrm{~s} \\
\mathrm{v}\end{array}$ & $\begin{array}{l}\text { Arts education aims should be } \\
\text { systematically planned across } \\
\text { various subject areas }\end{array}$ & 3.708 & $\begin{array}{l}\text { Training at the faculty } \\
\text { encourages development of } \\
\text { future teachers' creative abilities }\end{array}$ & 3.524 & & \\
\hline $\begin{array}{l}\text { Arts education strengthens } \\
\text { personal and collective identity }\end{array}$ & $\begin{array}{r}\mathrm{P} \\
3.877 \mathrm{c} \\
\mathrm{a}\end{array}$ & $\begin{array}{l}\text { Primary schools should have } \\
\text { cultural coordinators to manage } \\
\text { arts and culture activities }\end{array}$ & 3.705 & $\begin{array}{l}\text { Training at the faculty offers } \\
\text { future teachers information on } \\
\text { the importance of the } \\
\text { social-emotional competence of } \\
\text { teachers }\end{array}$ & 3.388 & & \\
\hline \multicolumn{8}{|c|}{$\begin{array}{l}\text { Arts education encourages } \\
\text { development of interdisciplinary } 3.870 \\
\text { knowledge, skills and } \\
\text { competences }\end{array}$} \\
\hline $\begin{array}{l}\text { Arts education can help solve } \\
\text { the problems of modern society }\end{array}$ & 3.384 & & & & & & \\
\hline Total & 3.872 & 3.788 & & 3.616 & & 4.169 & \\
\hline
\end{tabular}

such as the promotion of partnerships between schools, artists and cultural institutions; the need for additional professional training; planning the goals of arts education in the framework of different subjects with the cultural coordinator. Students are also critical toward the content of the education of future teachers at university level. While admitting that they had gained a sound professional and general knowledge in the framework of their university studies, they regretted that their creative abilities and socio-emotional competences could not be fully expressed.

Bresler (1998) thinks that the contexts in which the arts operate in schools do not enhance pupils' creativity; therefore, she suggests a systematic approach to aim-oriented planning of arts education. In line with Šuvakovič's (2007) observations, it is necessary "to replace the accumulation of positivistic knowledge, dates and data with a critical analysis and a consideration of the positive effects and the reception of a work of art; it is necessary to emphasize pupils' individual contributions, their ability to self-organize and self-reflect, to replace the authoritative teacher with a mass of critical and investigative actors, and listen to the voices of culture and the art itself" (Šuvakovič, 2007: p. 14). Vasudevan and Hill (2008) ask what chance there is for different learning at school after the media and media texts have become part of the learning materials. Arts teachers should be familiar with the advantages and disadvantages of various media, new technologies and their use in the classroom. Because teachers use the media as a way of expressing and forming identity, the teacher should have a command of information-communication technology. For this reason, teacher training should familiarize teachers with the use of new technologies for the purpose of artistic expression and provide them with the chance to teach with internet help.
Therefore, the obtained results serve as a reminder that teachers who prepare subjects and teach in the field of the arts should possess sufficient pedagogical-didactic knowledge and skills, the ability to create and perform works of art and the ability to analyze, interpret and evaluate works of art. They should also have developed the personality potential and social and emotional competencies that manifest themselves in a responseble view of the aesthetic development of students, in a positive attitude towards culture and the arts, and in the expression of joy and interest in a particular type of art.

Students from different study programs differed in their attitude towards education and art which is confirmed by the following results (see Table 2).

The assumption on the homogeneity of variances is violated in the third section (the content of the education of future teachers), which is why in this case we refer to Welch's approximation F-test, and in the remainder we rely on the outcome of the usual F-test. These results reveal the existence of statistically significant differences between students from different study programs in their attitude to the importance of art education $(P=.005)$ and regarding the measures needed to improve the quality of arts and cultural education $(P=.000)$. Arts education was given greater importance by students of social sciences $(\bar{x}=23.99)$, preschool education $(x=23.36)$, and students of class teaching $(\bar{x}=22.99)$ than by students of natural sciences $(\bar{x}=22.47)$. The latter, in other words students of natural sciences, are also more reserved than students of other study programs regarding measures for raising the quality of arts and cultural education. Why students of natural sciences place little importance on arts education can be found in the nature of this science, and in the fact that the focus of interest at elementary and secondary school level is more on natural sci- 
Table 2.

The results of the analysis of the variance in four sets of students' attitudes with respect to the study program.

\begin{tabular}{|c|c|c|c|c|c|c|c|c|}
\hline \multirow[t]{2}{*}{ Sets } & \multirow[t]{2}{*}{ Study program } & \multirow{2}{*}{$\begin{array}{c}\text { Numerous } \\
\mathrm{n}\end{array}$} & \multirow{2}{*}{$\begin{array}{c}\text { Mean } \\
\bar{x}\end{array}$} & \multirow{2}{*}{$\begin{array}{c}\text { Standard deviation } \\
\mathrm{S} \\
\end{array}$} & \multicolumn{2}{|c|}{$\begin{array}{l}\text { Test of homogeneity of } \\
\text { variances }\end{array}$} & \multicolumn{2}{|c|}{$\begin{array}{l}\text { Test of differences between } \\
\text { means }\end{array}$} \\
\hline & & & & & $\mathrm{F}$ & $P$ & $\mathrm{~F}$ & $P$ \\
\hline \multirow{4}{*}{ Importance of arts education } & Class teaching & 189 & 22.9894 & 3.06662 & \multirow{4}{*}{1.603} & \multirow{4}{*}{.188} & \multirow{4}{*}{4.264} & \multirow{4}{*}{.005} \\
\hline & Preschool education & 128 & 23.3594 & 3.51540 & & & & \\
\hline & Natural sciences & 98 & 22.4694 & 3.64452 & & & & \\
\hline & Social sciences & 137 & 23.9927 & 3.61471 & & & & \\
\hline \multirow{4}{*}{$\begin{array}{l}\text { Measures for raising the quality of } \\
\text { arts and cultural education }\end{array}$} & Class teaching & 189 & 14.9418 & 2.39942 & \multirow{4}{*}{.730} & \multirow{4}{*}{.535} & \multirow{4}{*}{10.865} & \multirow{4}{*}{.000} \\
\hline & Preschool education & 128 & 15.4531 & 2.39376 & & & & \\
\hline & Natural sciences & 98 & 14.1633 & 2.54726 & & & & \\
\hline & Social sciences & 137 & 15.8686 & 2.25185 & & & & \\
\hline \multirow{4}{*}{ Content of future teacher training } & Class teaching & 189 & 14.7090 & 2.30055 & \multirow{4}{*}{3.177} & \multirow{4}{*}{.024} & \multirow{4}{*}{1.252} & \multirow{4}{*}{.291} \\
\hline & Preschool education & 128 & 14.4141 & 2.76516 & & & & \\
\hline & Natural sciences & 98 & 14.3265 & 2.12387 & & & & \\
\hline & Social sciences & 137 & 14.2774 & 1.99533 & & & & \\
\hline \multirow{4}{*}{ Team planning of education work } & Class teaching & 189 & 8.4762 & 1.25720 & \multirow{4}{*}{.811} & \multirow{4}{*}{.488} & \multirow{4}{*}{1.216} & \multirow{4}{*}{.303} \\
\hline & Preschool education & 128 & 8.2422 & 1.36172 & & & & \\
\hline & Natural sciences & 98 & 8.2041 & 1.47808 & & & & \\
\hline & Social sciences & 137 & 8.3358 & 1.32422 & & & & \\
\hline
\end{tabular}

ences and less on arts and cultural education.

We were also interested in the extent to which the students' opinions were conditioned by their willingness to make the same choice of study program now as they did three years ago (see Table 3).

In two sets (the importance of arts education, the content of the education of future teachers), where the assumption of homogeneity of variance is violated $(P<.05)$, we rely on the result of approximation, and in the remainder on the result of the general F-test.

Concerning their willingness to re-enroll in the same programme, a statistically significant difference occurred only in the set of attitudes relating to the content of future teachers education $(P=.000)$. Encouraging the development of students' creative abilities and offering a sound professional and general knowledge at university level, alongside content on the importance of the teachers' socio-emotional competencies in teacher training programmes, were most strongly supported by those students who would after three years have chosen the same study program as before and least by those who would after three years contemplate a different study program. This suggests, therefore, that the decision of students on a career change is conditioned by their restricted options for developing creative abilities and socio-emotional competences, rather than by the acquired professional and general knowledge.

The teacher indirectly and directly contributes to the rise and fall of the quality of educational work. Certain properties such as the teacher's emotional warmth, correctness in communication, creativity, efficiency, patience, and consistency are, therefore, some of the most important factors in a successful educational process.

\section{Conclusion}

The results of this research serve as a reminder that teachers at three Slovene universities often practice most of the general goals of the arts and cultural education in the study process; however, not nearly enough attention is paid to understanding of cultural diversity and shaping attitudes towards cultural val- ues. The findings also reveal that the students support a series of measures aimed at improving the quality of arts and cultural education in the education system. Their approval of team (cross-subject) planning, the need for professional training of teachers in cultural and art education, and the promotion of partnerships between schools, artists and cultural institutions, are especially worthy of mention. Even though education policy recognizes a number of educational, cultural and social benefits of arts education, we can see that education in and through the arts still remains in need of effective implementation in programmes (Bamford, 2006). This brings us to the problems of training those who implement arts programmes (teachers and artists), of providing access to relevant information, of settingup active partnerships between educational and cultural institutions, of overcoming the borders between school and the afterschool environment and of flexibility in programme implementtation.

This raises the question of whether the aims of arts and cultural education should be pursued in arts subjects as individual subjects or in relation to other subject areas. The integration of art into the education system no doubt requires a systematic analysis of cross-subject integration on the level of aims and content (Kalin \& Kind, 2006; Larson \& Walker, 2006). There is still much to be done in order to fully develop concrete didactic approaches or implement the aims of arts and cultural education in other subject areas of the curriculum, not only in theory but also in practice.

Last but not least, it is necessary to emphasize that, according to students, faculties that train teachers offer sound professional and general-education knowledge; however, they pay insufficient attention to the development of creative abilities and the importance of the social and emotional competence of future teachers. Results of studies concerning youth culture and education (Heath, 2001) also caution that schools still insufficiently exploit their potential as places of creativity and striving for new art forms (Schacter, Thum, \& Zifkin, 2006). The traditional channels of creativity and cultural participation of young people in Slovenia are still present even today (e.g., creating music, singing and dancing, artistic activities, watching films, 
Table 3.

The results of the analysis of variance in four sets of students' attitudes with respect to interest.

\begin{tabular}{|c|c|c|c|c|c|c|c|c|}
\hline \multirow[t]{2}{*}{ Sets } & \multirow[t]{2}{*}{ Interest } & \multirow{2}{*}{$\begin{array}{c}\text { Numerous } \\
\mathrm{n}\end{array}$} & \multirow{2}{*}{$\begin{array}{c}\text { Mean } \\
\bar{x} \\
\end{array}$} & \multirow{2}{*}{$\begin{array}{c}\text { Standard deviation } \\
\mathrm{s}\end{array}$} & \multicolumn{2}{|c|}{$\begin{array}{c}\text { Test of homogeneity of } \\
\text { variances }\end{array}$} & \multicolumn{2}{|c|}{$\begin{array}{c}\text { Test of differences } \\
\text { between means }\end{array}$} \\
\hline & & & & & $\mathrm{F}$ & $P$ & $\mathrm{~F}$ & $P$ \\
\hline Importance of arts education & $\begin{array}{c}\text { Yes } \\
\text { No } \\
\text { Undecided }\end{array}$ & $\begin{array}{c}348 \\
54 \\
114\end{array}$ & $\begin{array}{l}23.1563 \\
23.0926 \\
23.5526\end{array}$ & $\begin{array}{l}3.48538 \\
4.03414 \\
3.00764\end{array}$ & 3.144 & .044 & .752 & .474 \\
\hline $\begin{array}{l}\text { Measures for raising the quality of arts and cultural } \\
\text { education }\end{array}$ & $\begin{array}{c}\text { Yes } \\
\text { No } \\
\text { Undecided }\end{array}$ & $\begin{array}{c}348 \\
54 \\
114\end{array}$ & $\begin{array}{l}15.2266 \\
15.0926 \\
14.9298\end{array}$ & $\begin{array}{l}2.33225 \\
2.92851 \\
2.60944\end{array}$ & 1.334 & .264 & .660 & .517 \\
\hline Content of future teacher training & $\begin{array}{c}\text { Yes } \\
\text { No } \\
\text { Undecided }\end{array}$ & $\begin{array}{c}348 \\
54 \\
114\end{array}$ & $\begin{array}{l}14.7734 \\
13.0556 \\
14.0965\end{array}$ & $\begin{array}{l}2.15538 \\
3.08629 \\
2.14505\end{array}$ & 6.475 & .002 & 10.874 & .000 \\
\hline Team planning of education work & $\begin{array}{c}\text { Yes } \\
\text { No } \\
\text { Undecided }\end{array}$ & $\begin{array}{c}348 \\
54 \\
114\end{array}$ & $\begin{array}{l}8.3932 \\
8.3148 \\
8.1667\end{array}$ & $\begin{array}{l}1.31035 \\
1.27122 \\
1.46291\end{array}$ & .401 & 670 & 1.267 & .283 \\
\hline
\end{tabular}

visiting museums, theatres, performances...); however, they are no longer necessarily dominant (Kirbiš, 2010). Creativity and cultural borders can no longer be examined simply through conventional forms of participation. It is necessary to tackle the diversity of cultural production and creativity which is, among young people in particular, increasingly associated with information and communication technology (ICT), especially the Internet (Pronovost, 2002). For this reason, it is necessary to consider a restructuring of education programs or appropriate and effective training of future class and subject teachers. In addition to this, it would be beneficial to introduce a systematically designed system of permanent professional education that would provide additional training and development of the abilities, skills and knowledge required for the successful planning, implementation and evaluation of the education process in various fields.

Studies of cultural education in Slovenia (Culture Education: Accessibility of Culture and Integration Between Culture and Education-A Search for Conceptual Solutions, 2005; Culture Education-Evaluation Study, 2004) point out that schools receive cultural content; that there exists a one-sided relationship between educational and cultural institutions that is not based on partnership; that more attention needs to be dedicated to effective cooperation between institutions and further training of pedagogical and cultural workers, as results demonstrate that the inclusion of cultural content in schools depends on the initiative and resourcefulness of teachers. Students included in our researchare also aware that we will have to do more to raise the quality of arts and cultural education at all levels of education. It is vital that the arts in education receive an equal, independent status compared to other subject areas. Supporters of this stance see arts education as a way of encouraging pupils and students to be the co-creators of the education process and not only passive recipients of knowledge from others.

In Slovenia, intensive integration of arts and culture values in the education system no doubt represents a long-term strategy of more efficient arts and cultural education. In order to make arts and culture values (once more) a criterion of modern education, we need cultural programmes of better quality in education and education programmes in culture, more appropriate levels of financial support, a broader and better network of partnerships and coordinators of arts and culture activities, training of professional workers in education and culture and examples of good practice.

\section{REFERENCES}

Arts Education Partnership, United States Department of Education (2004). The arts and education: New opportunities for research. Washington: Arts Education Partnership.

Bamford, A. (2006). The wow factor: Global research compendium on the impact of the arts in education. Berlin: WaxmannVerlag.

Bevc, V. (2005). Interdisciplinary planning and connecting educational process. In T. Rupnik Vec (Eds), Encouraging the active role of students in the classroom (pp. 50-89). Ljubljana: Zavod Republike Slovenijezašolstvo.

Borota, B. (2008). The art and music in the changing society. Music in School, 13, 3-10.

Bresler, L. (1998). "Child art", "fine art" and "art for children": The shaping of school practice and implications for change. Arts Education Policy Review, 100, 3-11.

Bresler, L. (2006). Toward connectedness: Aesthetically based research. studies in art education. Journal of Issues and Research, 48, 52-69. doi:10.1080/10632919809599444

Culture education (2005). Accessibility of culture and integration between culture and education-A search for conceptual solutions. URL (last checked 23 January 2012).

http://www.mk.gov.si/fileadmin/mk.gov.si/pageuploads/Ministrstvo/r aziskaveanalize/umetnost/Kulturna_vzgoja_november_2005.pdf

Cultural education (2004). Evaluation study. URL (last checked 13 February 2012).

http://www.mk.gov.si/filead-min/mk.gov.si/pageuploads/Ministrstvo/ razikave-analize/umetnost/Kulturna_vzgoja_evalvacijska_studija.pdf

European Union (2008). Work plan for culture 2008-2010. URL (last checked 10 September 2011).

www.dlib.si/v2/StreamFile.aspx?URN=URN:NBN:SI:doc...id

European Union (2010). Communication on a European agenda for culture in a globalising world. URL (last checked 13 October 2011). http://heur-lex.europa.eu/LexUriServ/LexUriServ.do?uri=COM:2007

Eurydice (2009). Arts and cultural education at school in Europe. Brussels: EACEA/Eurydice P9.

Heath, S. B. (2001). Three's not a crowd: Plans, roles, and focus in the arts. Educational Researcher, 30, 10-17. doi: 10.3102/0013189X030007010

Kalin, N. \& Kind, S. (2006). Invitations to understanding: Explorations in the teaching of arts to children. Arts Education, 59, 36-41.

KEA European Affairs (2009). The impact of culture on creativity. Study prepared for the European commission, directorate general for education and culture. Brussels: KEA European Affairs.

Kirbiš, A.(2010). Culture and art in education-Guide of 21st Century (pp. 249-278). Ljubljana: Aristej.

Larson, R. W., \& Walker, K. C. (2006). Learning about the "real world" in an urban arts youth program. Journal of Adolescent Research, 21, 244-268. doi:10.1177/0743558405285824

Požar Matijašič, N., Bucik, N., Tome, S., Germ, T., Hrženjak, M., Lu- 
kan, B. et al. (2008). Kultura in umetnost v izobraževanju-Popotnica 21 stoletja. Ljubljana: Pedagoški inštitut.

President's Committee on the Arts and the Humanities (2011). Reinvesting in arts education. Winning America's future through creative schools. Washington DC: President's Committee on the Arts and the Humanities.

Pronovost, G. (2002). A review of surveys on cultural participation. URL (last checked 10 November 2011).

http://www.colloque2002symposium.gouv.qc.ca/PDF/Pronovost_pap er Symposium.pdf

Republic of Slovenia, Ministry of Culture (2008). National cultural programme 2008-2011. URL (last checked 13 February 2012).

www.kultura.gov.si

Republic of Slovenia, Ministry of Culture (2009). Proposal of arts and cultural education. URL (last checked 14 January 2012).

www.mk.gov.si/fileadmin/mk.gov.si/.../Kulturna_vzgoja_2009.pdf/

Russel, J., \& Zembylas, M. (2007). Arts integration in the curriculum: A review of research and implications for teaching and learning. In L. Bresler (Ed.), International handbook of research in arts education (pp. 287-303). Dordrecht: Springer. doi:10.1007/978-1-4020-3052-9 18

Schacter, J., Thum, Y. M., \& Zifkin, D. (2006). How much does creative teaching enhance elementary school students' achievement? Journal of creative behavior, 40, 47-72.

doi:10.1002/j.2162-6057.2006.tb01266.x

Schirrmacher, R. (2002). Art and creative development for young chil- dren. Albany, NY: Delmar Thomson Learning.

Sharp, C., \& Le Métais, J. (2000). The arts, creativity and cultural education: An international perspective (International review of curriculum and assessment franeworks project). London: Qualifications and Curriculum Authority.

Šuvakovič, M. (2007). Epistemology of learning art. Maska, 22, 14-22.

Taggart, G., Whitby, K., \& Sharp, C. (2004). Curriculum and progression in the arts: An international study, final report. London: Qualifications and Curriculum Authority.

Thompson, C. M. (2006). Repositioning the visual arts in early childhood education: A decade of reconsideration. In B. Spodek, \& O. Saracho (Eds.), Handbook of research on the education of young children (pp.223-242). Mahwah, NJ: Lawrence Erlbaum.

UNESCO (2006). Road map for arts education. URL (last checked 10 October 2012).

http://portal.unesco.org/culture/en/ev.php-URL_ID=30335\&URL

Vasudevan, L., \& Hill, M. L. (2008). Moving beyond dichotomies of media engagement in education: An introduction. In M. L. Hill, \& L. Vasudevan (Eds.), Media, learning, and sites of possibilty (pp. 1-12). New York: Peter Lang.

Zavod Republike Slovenije za šolstvo (2009). National Guidelines for Arts and Cultural Education. URL (last checked 23 Junuary 2012). www.zrss.si/doc/SLO_Vlado $\% 20 \% 20$ Potrjene $\% 20$ smernice.doc

Zbainios, D., \& Anastasopoulou, A. (2012). Creativity in Greek music curricula and pedagogy: An investigation of Greek music teachers perceptions. Creative education, 3, 55-60. 